\title{
Pancasila dalam Kurikulum Pendidikan di Indonesia dari Masa ke Masa: Urgensi atau Simbolisasi
}

\author{
Fara Azkiya Okta Faharani \\ Universitas Pembangunan Nasional "Veteran" Yogyakarta \\ 114200059@student.upnyk.ac.id
}

\begin{abstract}
ABSTRAK
Pancasila sebagai dasar negara sekaligus falsafah bangsa Indonesia lahir melalui proses yang panjang. Pancasila mulai diterapkan dalam kurikulum pembelajaran sejak tahun 1957 pada saat pemerintahan Ir. Soekarno dengan sebutan pelajaran Kewarganegaraan. Kemudian mengalami perubahan pada tahun 1961 menjadi civics. Pada tahun 1968 berubah kembali menjadi Pendidikan Kewargaan Negara. Hingga perubahan terakhir yaitu pada kurikulum 2013. Selama masa perubahan itu, Pendidikan Pancasila mengalami perubahan-perubahan baik dari nama ataupun cakupan bahasannya. Penelitian ini bertujuan untuk memaparkan sejarah serta urgensi pendidikan Pancasila dalam kurikulum pembelajaran. Metode penelitian ini yaitu studi pustaka. Pendidikan Pancasila menjadi salah satu 'tameng' awal dalam kehidupan berbangsa dan bernegara untuk menhadapi ancaman dan tantangan lunturnya nilai luhur yang terkandung dalam Pancasila. Pendidikan Pancasila bukanlah sebagai simbolisasi melainkan suatu hal yang penting dalam mempertahankan pondasi bangsa ini. Pendidikan Pancasila hendaknya dapat dipertahankan dalam kurikulum dengan menyesuaikan tren pembelajarannya. Selain itu, pengembangan metode pembelajaran juga sangat diperlukan guna meningkatkan mutu dari Pendidikan Pancasila yang dipelajari oleh peserta didik.
\end{abstract}

Kata Kunci: Pendidikan Pancasila, Pancasila, Nilai luhur, kurikulum.

\begin{abstract}
Pancasila as the basis of the state as well as the philosophy of the Indonesian nation was born through a long process. Pancasila began to be applied in the learning curriculum since 1957 during the government of Ir. Soekarno with the title of Citizenship lesson. Then changed in 1961 to civics. In 1968 it changed back to State Citizenship Education. Until the last change, namely the 2013 curriculum. During the period of change, Pancasila Education underwent changes both in terms of name and scope of discussion. This study aims to describe the history and urgency of Pancasila education in the learning curriculum. This research method is literature study. Pancasila education is one of the initial 'shields' in the life of the nation and state to face the threats and challenges of the disappearance of the noble values contained in Pancasila. Pancasila education is not a symbol but an important thing in maintaining the foundation of this nation. Pancasila education should be maintained in the curriculum by adjusting the learning trends. In addition, the development of learning methods is also very necessary in order to improve the quality of Pancasila education that is learned by students.
\end{abstract}

Keywords: Pancasila education, Pancasila, noble values, curriculum. 


\section{PENDAHULUAN}

Pancasila mulai dikenalkan oleh Ir. Soekarno pada saat sidang BPUPKI yang diselenggarakan pada tanggal 1 Juni 1945 saat menyampaikan gagasan dasar negara Indonesia. Di sidang yang berlangsung dari 29 Mei hingga 1 Juni 1945 itu mencakup gagasan-gagasan dasar negara dari beberapa tokoh lain yaitu antara lain Moh. Yamin dan Mr. Soepomo. Gagasan dasar negara yang disampaikan Ir. Soekarno pada tanggal 1 Juni 1945 diusulkan agar dinamai dengan "Pancasila" yang mana nama tersebut disebutkan berasal dari saran teman Ir. Soekarno sendiri yang merupakan seorang ahli bahasa (Brata, I. B., \& Wartha, I. B. N., 2017). Pancasila sendiri memiliki arti yaitu lima sila. Lima sila dasar negara yang akhirnya disahkan pada tanggal 18 Agustus 1945 pun dinamai dengan Pancasila.

Rumusan konsepsi Pancasila benarbenar dititikberatkan pada dan sesuai dengan karakter bangsa (Huda, M. C., 2018). Pancasila merupakan ekstraksi dari karakter bangsa Indonesia yang telah berkembang sejak dahulu. Eksistensi Pancasila dapat tetap bertahan walau kisruh politik melanda karena Pancasila adalah media pemersatu bangsa yang mengandung nilai-nilai toleransi dan harmonisasi bersifat terbuka mengikuti perkembangan zaman (Brata, I. B., \& Wartha, I. B. N., 2017). Dengan demikian, Pancasila dapat dikatakan memiliki sifat dinamis.

Lahirnya Pancasila sebagai dasar negara telah menjadi pernyataan tertulis terkait falsafah pandangan hidup bangsa Indonesia. Pancasila menyederhanakan kompleksitas dari falsafah hidup bangsa Indonesia itu sendiri. Pancasila sebagai falsafah hidup bangsa menjadi pondasi pilarpilar bangsa Indonesia. Pondasi tersebut hendaknya dapat dijaga dan diperkuat jikalau bisa. Pancasila sebagai pandangan hidup bangsa juga berfungsi sebagai penunjuk arah kemana bangsa Indonesia akan mengarah.

Pancasila sebagai ideologi bangsa lahir melalui pemikiran yang mendalam terkait pandangan hidup dan jiwa bangsa Indonesia. Berdasarkan pidato yang disampaikan oleh Ir. Soekarno, Pancasila juga telah melalui pemikiran yang digali secara mendalam sejak dulu seperti halnya paham-paham lainnya seperti Marxisme, Naziisme dan sebagainya. Paham atau ideologi merupakan operasionalisasi sistem filsafat suatu bangsa sehingga ideologi bangsa Indonesia yaitu ideologi Pancasila merupakan bentuk operasionalisasi filsafat bangsa Indonesia (Widisuseno, I., 2014).

Pancasila bukan berupa paham liberalisme, kapitalisme, sosialisme ataupun yang lainnya tetapi Pancasila merupakan paham atau ideologi yang terbuka yang mana ideologi tersebut berupa kristalisasi ide, cita-cita dan keyakinan bangsa yang sudah dimiliki oleh masyarakat Indonesia Gultom, A., 2021). Pancasila sejatinya telah melekat dalam diri masyarakat Indonesia. Hal tersebut dicerminkan oleh perilaku dan kepribadian bangsa dalam implementasi nilai Pancasila. Implementasi Pancasila inilah yang menjadi salah satu poin yang dapat mempertahankan eksistensi Pancasila dalam kehidupan berbangsa dan bernegara. Realisasi nilai-nilai Pancasila sudah seharusnya menjadi kewajiban moral dalam kehidupan tersebut(Hadiwijono, A., 2016).

Pancasila memiliki nilai-nilai luhur yang hendaknya dapat diterapkan dalam kehidupan sehari-hari. Hakikat dari implementasi Pancasila dalam kehidupan bermasyarakat yaitu realisasi praksis untuk mencapai tujuan bangsa (Gultom, A., 2021). Penanaman nilai Pancasila dan implementasinya mulai diterapkan dalam pendidikan dilakukan melalui adanya kurikulum pendidikan pancasila. Darmadi, H. (2020) dalam bukunya menjelaskan kronologi perjalanan pendidikan Pancasila dari masa ke masa. Pendidikan Pancasila pertama muncul berupa pelajaran Kewarganegaraan yang dimulai pada tahun 1957 di masa pemerintahan Ir. Soekarno. Kemudian dilanjut dengan yang pada masa itu lebih dikenal dengan istilah civics yang baru dimulai di sekolah-sekolah dimulai pada tahun 1961 menggantikan pelajaran Kewarganegaraan. Di tahun 1968, Pendidikan Kewargaan Negara menggantikan civics. Berikutnya yaitu Pendidikan Moral Pancasila (PMP) yang dimulai pada tahun 1975 dan 1984 yang kemudian digantikan dengan Pendidikan Pancasila dan Kewarganegaraan (PPKn) pada tahun 1994. Di tahun 2004 kembali menjadi pelajaran Kewarganegaraan yang pada tahun 2006 berganti menjadi 
Pendidikan Kewarganegaraan setelah keluarnya Standar Isi dan Standar Kompetensi mata pelajaran. Kemudian perkembangan yang terakhir dalam buku ini yaitu keluarnya kurikulum 2013 (K-13) menggantikan kurikulum 2006 dimana PPKn dalam kurikulum ini mencakup bahasan 4 pilar kebangsaan yaitu UUD 1945, Pancasila, Bhineka Tunggal Ika dan NKRI (Darmadi, H., 2020).

Pendidikan Pancasila dalam kurikulum pembelajaran di Indonesia diatur dalam UU nomor 20 tahun 2003 tentang Sistem Pendidikan Nasional yang mana menjelaskan bahwa Pendidikan Nasional berlandaskan hukum dari Pancasila (Halim, A., Mentari, A., \& Yanzi, H., 2019).

Pendidikan Pancasila telah menjadi bagian dari kehidupan masyarakat Indonesia. Pendidikan Pancasila merupakan pendidikan terkait nilai luhur dan falsafah bangsa. Dimana dalam pendidikan ini selayaknya mencakup teori serta implementasinya. Implementasi dalam pendidikan Pancasila berperan sebagai salah satu bentuk perwujudan secara nyata dari teori serta pandangan hidup bangsa dalam kehidupan. Cakupan pembelajaran dalam Pendidikan Pancasila memiliki perbedaan dari masa awal muncul yaitu pada tahun 1957 hingga pada saat ini.

Adanya Pancasila dalam kurikulum pendidikan memiliki tujuan yang berbeda di setiap periode perubahannya. Hal ini mungkin dilakukan untuk menyesuaikan dengan perubahan-perubahan yang terjadi seperti halnya globalisasi. Globalisasi membawa perubahan baik dari segi budaya ataupun pendidikan. Hadirnya globalisasi dapat menjadi salah satu ancaman lunturnya implementasi Pancasila. Selain itu, Pancasila dapat saja tinggal nama karena lunturnya implementasi tersebut. Lunturnya hal ini tentunya perlu dicegah dengan langkahlangkah tertentu yang dapat dimulai dari kehidupan sehari-hari.

Selain itu, beberapa ada yang mengatakan bahwa pendidikan Pancasila merupakan bentuk indoktrinasi. Selain itu, juga ada yang mengatakan bahwa pendidikan ini dapat saja merupakan tujuan politik oleh suatu pihak oknum terkait. Namun sebenarnya pendidikan Pancasila merupakan sebuah urgensi atau hanya sebagai sarana untuk mencapai tujuan politik oknum tertentu. Hal tersebut masih menjadi pertanyaan beberapa orang meskipun sampai saat ini pendidikan Pancasila masih berjalan.

\section{METODE}

Metode penelitian yaitu suatu cara atau proses ilmiah yang bertujuan untuk mendapatkan data dengan kegunaan ataupun tujuan tertentu (Sugiyono dalam Karmanis \& Karjono, 2020). Metode yang digunakan dalam penelitian ini yaitu metode studi putaka. Metode ini merupakan metode pengumpulan data melalui studi kepustakaan baik untuk menggali informasi ataupun melakukan telaah. Metode ini merupakan metode yang paling tepat dalam penelitian dalam tulisan ini. Instrumen dalam metode penelitian ini yaitu berupa olah pikir penulis dari data yang telah didapat guna menemukan solusi pada permasalahan yang dibahas. Analisa data pada penelitian ini dilakukan dengan pengolahan data yang didapat melalui studi pustaka yang kemudian dilakukan pemecahan masalah.

\section{HASIL DAN PEMBAHASAN}

Pancasila mulai diterapkan pada pendidikan melalui pembelajaran di sekolah sejak setelah kemerdekaan. Pendidikan Pancasila mulai diterapkan dari tahun 1957 saat pemerintahan Ir. Soekarno hingga saat ini. Pendidikan Pendidikan Pancasila yang diterapkan pun mengalami perubahan dari masa ke masa.

\section{Pendidikan Pancasila dari Masa ke Masa}

Pendidikan Pancasila mulai diterapkan dalam pembelajaran pada tahun 1957. Pendidikan Pancasila pada masa itu disebut dengan Kewarganegaraan. Kemudian pada tahun 1961, pelajaran tersebut digantikan oleh civics. Pelajaran ini berisi tentang aspek teoretis terkait warga negara dan pemerintah dan hubungan antar warga negara dan pemerintah (Darmadi, H., 2020). Pada tahun 1968, Pendidikan Kewargaan negara menggantikan civics. Perubahan ini dilanjut dengan Pendidikan Moral Pancasila (PMP) terkait adanya kurikulum tahun 1975 dan 1984. Pelajaran tersebut kemudian diganti dengan Pancasila dan Kewarganegaraan (PPKn) pada tahun 1994. Di tahun 2004 berubah kembali 
menjadi pelajaran Kewarganegaraan yang kemudian pada tahun 2006 berganti menjadi Pendidikan Kewarganegaraan setelah keluarnya Standar Isi dan Standar Kompetensi mata pelajaran. Kemudian perkembangan yang terakhir dalam buku ini yaitu keluarnya kurikulum 2013 (K-13) menggantikan kurikulum 2006 dimana PPKn dalam kurikulum ini mencakup bahasan 4 pilar kebangsaan yaitu UUD 1945, Pancasila, Bhineka Tunggal Ika dan NKRI. Aspek penilaian dalam kurikulum ini juga lebih tinggi tingkatannya daripada kurikulum sebelumnya.

\section{Kurikulum Pendidikan Pancasila}

Kurikulum pendidikan nyaris selalu berubah setiap terjadi pergantian menteri pendidikan dan kebudayaan. Pergantian kurikulum ini dapat saja ditujukan pada pemutakhiran pendidikan di Indonesia dalam kemajuan ilmu pengetahuan dan teknologi (IPTEK). Di masa pemerintahan Ir. Soekarno, pendidikan cenderung bersifat politis (Darmadi, H., 2020). Pendidikan nasional yang ditetapkan oleh Ir. Soekarno di era Demokrasi Terpimpin dinilai digunakan sebagai alat manifesto politik. Kemudian pada masa Orde Baru, dilakukan koreksi dan restrukturalisasi Pancasila dan UUD 1945 yang diterapkan pada Orde Lama. Pendidikan pada era ini dilakukan dengan permurnian ulang Pancasila dan UUD 1945 sehingga terjadi penghapusan pelajaran civics pada tahun 1970-an. Melalui GBHN dari TAP MPR No IV Tahun 1973, menerangkan bahwa setiap warga negara wajib memahami Pedoman Penghayatan dan Pengamalan Pancasila (P4). PMP mulai diterapkan pada pembelajaran disekolah melalui kurikulum 1975. Pada tahun 1984 diberlakukan kurikulum 1984 dimana terdapat input mata pelajaran baru yang tumpang tindih dengan $\mathrm{P} 4$ dan PMP yaitu Pendidikan Sejarah dan Perjuangan Bangsa (PPSB). Pada tahun 1994, PMP kemudian berubah nama saat diberlakukannya kurikulum 1994 menjadi Pendidikan Pancasila dan Kewarganegaraan (PPKn). Kemudian pada tahun 2006 terjadi perubahan kurikulum sesuai keluarnya Standar Isi dan Standar Kompetensi mata pelajaran yang menggantikan pelajaran tersebut menjadi Pendidikan
Kewarganegaraan. Berikutnya setelah diberlakukan kurikulum 2013 (K-13) yang mencakup penilaian pembelajaran yang lebih dari kurikulum sebelumnya.

\section{Urgensi Pendidikan Pancasila}

Pada awal kemerdekaan, pemahaman dan edukasi terkait Pancasila sangatlah diperlukan. Urgensi adanya pendidikan Pancasila ini baru terealisasi pada tahun 1957 melalui pelajaran Kewarganegaraan dalam sekolah. Pendidikan Pancasila saat itu sangatlah dibutuhkan mengingat Indonesia yang baru saja merdeka.

Pendidikan Pancasila berfungsi sebagai sarana pembelajaran terkait nilainilai dan falsafah bangsa yang terkandung di dalamnya. Nilai-nilai tersebut merupakan nilai luhur yang menjadi falsafah hidup bangsa yang telah ada dalam kehidupan masyarakat Indonesia. Kehidupan tersebut tak lepas dari kehidupan sehari-hari yang dapat saja terpengaruh oleh faktor seperti salah satunya yaitu globalisasi.

Globalisasi menjadi gerbang penghubung dengan dunia internasional. Di era ini, semua informasi, budaya dan berbagai ilmu pengetahuan dan teknologi berkembang pesat seiring berjalannya waktu. Namun, tak dapat dipungkiri pula budaya luar dapat masuk ke Indonesia melalui globalisasi. Masuknya budaya luar dapat saja menimbulkan dampak positif ataupun negatif. Dampak positifnya yaitu dari masuknya budaya luar dapat memperluas pengetahuan terkait budaya lain di luar sana. Selain itu, budaya luar yang memiliki dampak baik serta tidak menyimpang dapat diterapkan dalam kehidupan. Namun, di sisi lain dampak negatif dari hal tersebut dapat saja terjadi. Salah satunya yaitu pengaruh gaya hidup yang negatif yang menyimpang dari nilai luhur dan pandangan hidup bangsa sehingga melunturkan nilai tersebut dari kehidupan. Hal ini tentunya patut diperhatikan baik-baik guna mempertahankan pondasi bangsa yaitu Pancasila.

Era globalisasi membawa perubahan dan perkembangan baik dari segi teknologi maupun pola pikir individu. Di era tersebut terjadi perubahan serta perkembangan sikap, pola pikir, tingkah laku, sosial, budaya, politik bahkan seluruh aspek yang ada 
(Alzanaa, A. W., \& Harmawati, Y., 2021). Perubahan tersebut tentunya menjadi tantangan yang mungkin dapat menimbulkan masalah-masalah dari keberagaman tersebut. Masalah-masalah tersebut diperlukan solisi sebagai langkah penyelesaian masalahnya. Peran Pendidkan Pancasila dapat menjadi penyelesaian masalah secara mendasar melalui penguatan karakter dan moral dari implementasi nilai-nilai yang terkandung di dalamnya.

Perkembangan IPTEK dan semakin berkembangnya globalisasi di era masa kini mengancam ketahanan dan nasionalisme bangsa (Apriliani, S. L., \& Dewi, D. A., 2021). Ketahanan nasional dapat terancam akibat adanya pengaruh eksternal maupun internal. Pengaruh eksternal merupakan pengaruh yang datang dari luar bangsa. Sementara pengaruh internal datang dari dalam bangsa itu sendiri.

Di masa kini, masa-masa dimana lunturnya nilai luhur Pancasila mulai tampak. Bahkan pada beberapa aspek sudah mulai menghilang. Pelestarian nilai luhur Pancasila menjadi sangatlah penting mengingat adanya hal-hal tersebut. Salah staunya yaitu dapat melalui pendidikan. Pembelajaran dapat menjadi salah satu sarana dalam mempertahankan sekaligus memperkuat fondasi bangsa melalui penanaman nilai-nilai Pncasila baik dari tingkat dini hingga tingkat tinggi.

Salah satu instrumen penting dalam kehidupan berbangsa serta bernegara yaitu Pendidikan Pancasila yang mana merupakan pelajaran terkait nilai dan pandangan hidup bangsa meskipun implementasi dari Pancasila tak hanya dapat dilakukan melalui pembelajaran di sekolah. Pendidikan Pancasila dapat berperan sebagai pendidikan dasar terkait Pancasila dan implementasinya sebagai bekal dalam perealisasian dalam kehidupan sehari-hari. Bekal dasar ini hendaknya dapat menjadi "perisai" awal untuk menghadapi ancaman lunturnya nilai luhur Pancasila.

Nilai praksis Pancasila hendaknya mampu mencoraki perilaku warga negara Indonesia (Sugianto, B., Taena, L., \& Bilu, L., 2019). Maksudnya, nilai praksis harusnya mampu tercermin dalam kehidupan berbangsa maupun bernegara. Tidak hanya tahu saja tetapi juga mampu merealisasikannya. Nilai luhur Pancasila takkan berarti apabila tak dapat direalisasikan.

\section{Pendidikan Pancasila sebagai Bekal Kehidupan Berbangsa dan Bernegara}

Pancasila sebagai bekal kehidupan berbangsa dan bernegara maksudnya pendidikan ini dapat menjadi langkah awal dan dasar dalam pengenalan, pemahaman dan penerapan terkait nilai luhur yang terkandung dalam Pancasila. Nilai luhur Pancasila diajarkan dalam bangku sekolah secara bertahap sesuai tingkat pendidikannya tanpa mengurangi esensi inti dari bahasannya. Pendidikan ini juga dapat menjadi langkah awal yang penting terutama dalam pengenalan pemahaman terkait nilainilai Pancasila.

Pemahaman terkait nilai Pancasila juga dapat menumbuhkan jiwa yang toleran dan jujur. Nilai-nilai Pancasila juga mengajarkan nilai religi, sosial, politik, budaya hingga hankam. Pendidikan Pancasila juga dapat diterapkan sebagai langkah awal dalam kewajiban bela negara sesuai yang tertuang dalam UUD 1945

\section{SIMPULAN}

Pendidikan Pancasila telah mengalami perubahan dari masa ke masa. Penerapan Pancasila dalam pendidikan dimulai pada tahun 1957. Pendidikan Pancasila dalam kurikulum pendidikan Indonesia bukan hanya sebuah simbolisasi saja tetapi sebagai suatu hal penting yang diusung sebagai 'tameng' awal dalam menghadapi ancaman lunturnya nilai luhur bangsa akibat berbagai faktor baik internal maupun eksternal. Pendidikan Pancasila dalam pembelajaran di sekolah diharapkan menjadi dasar dalam perwujudan nilai luhur bangsa dalam Pancasila di kehidupan sehari-hari.

\section{SARAN}

Pendidikan Pancasila hendaknya tetap ada dalam kurikulum pembelajaran di Indonesia. Untuk memaksimalkan mutu pembelajarannya juga perlu dilakukan penyesuaian metode pembelajaran dengan tren pembeljarannya. Pendidikan Pancasila seharusnya dapat menjadi dasar penguatan karakter dan moral guna mengahadapi 
tantangan-tantangan dalam kehidupan berbangsa serta bernegara.

\section{DAFTAR PUSTAKA}

Alzanaa, A. W., \& Harmawati, Y. (2021). Pendidikan Pancasila sebagai pendidikan multikultural. Citizenship Jurnal Pancasila dan Kewarganegaraan, 9(1), 51-57.

Apriliani, S. L., \& Dewi, D. A. (2021). Menyingkap Perkembangan Pengimplementasian Pancasila dari Masa ke Masa. EduPsyCouns: Journal of Education, Psychology and Counseling, 3(1), 21-30.

Brata, I. B., \& Wartha, I. B. N. (2017). Lahirnya Pancasila sebagai Pemersatu Bangsa Indonesia. Jurnal Santiaji Pendidikan (JSP), 7(1).

Darmadi, H. (2020). Apa Mengapa Bagaimana Pembelajaran Pendidikan Moral Pancasila Dan Pendidikan Pancasila Dan Kewarganegaraan (PPKn): konsep dasar strategi memahami ideologi pancasila dan karakter bangsa. An1mage.

Gultom, A. (2021). Implementasi Pancasila dalam Menjaga Eksistensi Bangsa. KAIS Kajian Ilmu Sosial, 30(1), 55-66.

Hadiwijono, A. (2016). Pendidikan Pancasila, eksistensinya bagi mahasiswa. Jurnal Cakrawala Hukum, 7(1), 82-97.

Halim, A., Mentari, A., \& Yanzi, H. (2019). Urgensi Mata Kuliah Umum Pendidikan Pancasila dalam Menanamkan Nilai Moral Budaya Bangsa pada Mahasiswa Memasuki Era Revolusi Industri 4.0. In Seminar Nasional Pendidikan Fakultas Keguruan dan Ilmu Pendidikan 2019, 03 Januari 2019, FKIP Universitas Lampung.

Huda, M. C. (2018). Meneguhkan Pancasila Sebagai Ideologi Bernegara. Resolusi: Jurnal Sosial Politik, 1(1), 78-99.

Karmanis \& Karjono. (2020). Buku Pedoman Belajar Metode Penelitian. CV. Pilar Nusantara

Sugianto, B., Taena, L., \& Bilu, L. (2019). Implementasi Pancasila Tantangan dan Solusinya. Gema

Pendidikan, 26(2), 10-19.

Widisuseno, I. (2014). Azas Filosofis Pancasila Sebagai Ideologi Dan Dasar Negara. Humanika, 20(2), 62-66.

\section{UCAPAN TERIMA KASIH}

Terima kasih pada dosen pengampu mata kuliah Pendidikan Pancasila yaitu bapak Lestanta Budiman yang telah berkenan membimbing dan menuntun selama setengah semester ini. Selain itu, penulis mengucapkan terima kasih pada para pembaca. Semoga tulisan ini dapat menambah wawasan terkait bahasan dalam tulisan ini.

\section{TENTANG PENULIS}

Fara Azkiya Okta Faharani (114200059), mahasiswa pertengahan awal tahun kedua Jurusan Teknik Lingkungan , Fakultas Teknologi Mineral, UPN "Veteran" Yogyakarta 